\title{
Rocky intertidal temperature variability along the southeast coast of Australia: comparing data from in situ loggers, satellite-derived SST and terrestrial weather stations
}

\author{
Justin A. Lathlean*, David J. Ayre, Todd E. Minchinton \\ Institute for Conservation Biology and Environmental Management \& School of Biological Sciences, \\ University of Wollongong, New South Wales 2522, Australia
}

\begin{abstract}
Predicting how both spatial and temporal variation in sea and air temperature influence the distribution of intertidal organisms is a pressing issue. We used data from satellites, weather stations and in situ loggers to test the hypothesis that satellite-derived sea surface temperatures (SSTs) and weather station air temperatures provide accurate estimates of ambient temperature variability on rocky intertidal shores for temporal (hourly for $1 \mathrm{yr}$ ) and spatial (10 $\mathrm{m}$ to $400 \mathrm{~km}$ ) variation along the southeast coast of Australia. We also tested whether satellites and weather stations accurately detect the duration, frequency and number of extreme temperature events. Daily mean satellite SSTs and weather station air temperatures were significantly and strongly correlated with intertidal water and air temperatures, respectively (water: $\mathrm{r}^{2}=0.62$, air: $r^{2}=0.63$ ). Nevertheless, depending on location, daily satellite SSTs were up to $6.7^{\circ} \mathrm{C}$, and on average $1^{\circ} \mathrm{C}$, higher than in situ water temperatures, while daily maximum air temperatures measured by weather stations were up to $23.2^{\circ} \mathrm{C}$, and on average $4.2^{\circ} \mathrm{C}$, lower than in situ air temperatures. At all locations, the frequency, duration and number of days greater than $30^{\circ} \mathrm{C}$, as well as rates of temperature change, were all significantly lower when measured by weather stations. These differences suggest that satellite SSTs and weather stations are ineffective at capturing extremes in intertidal water and air temperature variability. We reinforce the argument that in situ measurements that focus on biologically relevant variation are the only legitimate means of predicting the effects of temperature change on intertidal taxa.
\end{abstract}

KEY WORDS: Temperature data logger . Intertidal invertebrate • Remote sensing . Climate change · Extreme temperature events

Resale or republication not permitted without written consent of the publisher

\section{INTRODUCTION}

As air and sea temperatures continue to rise, remote sensing techniques, such as satellite-derived sea surface temperatures (SSTs), are becoming increasingly important tools in assessing how changes in temperature will influence the geographic distributions of species (Gilman et al. 2006, Helmuth 2009). It is well known, for example, that large-scale ocean temperature variability significantly influences physiological and demographic processes of many marine invertebrates, fish and primary producers, with shifts in species range limits associated with increased sea tem- peratures (Zacherl et al. 2003, Gilman 2006, Lima et al. 2006, Herbert et al. 2007, Last et al. 2011). Invertebrates living in intertidal habitats may be particularly vulnerable to fluctuating temperatures as they have to adapt to temperature extremes in both the terrestrial and marine environment (Fields et al. 1993). However, at relatively small spatial scales, such as across the vertical extent of a rocky intertidal shore, body temperatures of sessile and sedentary invertebrates can be determined by the timing and duration of aerial exposure (Helmuth et al. 2002), and studies have shown that air temperatures during low tide have greater effects on the physiological processes of both intertidal 
mussels and barnacles compared to water temperatures during high tide (Hofmann \& Somero 1995, Somero 2002). Therefore, both air and water measurements are required to characterise the thermal environment of rocky intertidal shores.

Several ecological studies have previously used satellite-derived SSTs to characterise the thermal environment of intertidal habitats (Barry et al. 1995, Broitman et al. 2001, 2005, 2008, Lagos et al. 2005, Herbert et al. 2007, Blanchette et al. 2008). Studies have shown that satellite-derived SSTs are highly correlated with daily in situ measurements of SST (Keogh et al. 1999, Barton \& Pearce 2006, Smale \& Wernberg 2009); nevertheless, satellite-derived SSTs are unlikely to reflect the variability of the temperature regimes experienced by the vast majority of rocky intertidal organisms (Helmuth \& Hofmann 2001, Gilman et al. 2006). Indeed, Helmuth \& Hofmann (2001) found that aerial body temperatures of the mussel Mytilus californianus varied independently of water temperatures and suggested that water temperatures by themselves should not be used as a measure of temperature stress for intertidal organisms.

Numerous factors operating across both large and small spatial scales pose difficulties when using remote sensing to estimate in situ temperatures on rocky intertidal shores. These include tidal dynamics and their variability among geographic locations (Helmuth et al. 2002, 2006, Harley 2008), degree of wave exposure and height on shore (Harley \& Helmuth 2003), as well as topographic orientation and slope of substratum (Helmuth \& Hofmann 2001, Harley 2008). As a result of this natural variability, even hourly temperature measurements commonly recorded by terrestrial weather stations and daily composite SST produced by satellite images are unlikely to detect acute (extreme) or chronic (continually stressful) temperature events, which are more likely to influence the mortality, growth and reproduction of intertidal organisms (Denny et al. 2006, 2009, Harley \& Paine 2009, Helmuth et al. 2010).

Southeast Australia has been identified as being particularly vulnerable to climate change and hosts many subtropical, warm-temperate and coldtemperate species (Hughes 2003, Poloczanska et al. 2007, Edgar 2008). SSTs along the southeast coast of Australia are largely influenced by the East Australian Current (EAC), which flows most strongly in the summer months and weakens during winter, usually deflecting offshore around Laurieton (31 $39^{\prime} \mathrm{S}$, $152^{\circ} 48^{\prime} \mathrm{E}$ ) in northern New South Wales (NSW), producing large warm-core eddies that penetrate the coastal waters of southern NSW and eastern Victoria
(Huyer et al. 1988, Roughan \& Middleton 2004). These southward-flowing warm-core eddies produce latitudinal temperature gradients and are expected to increase in strength, penetrating further south, under future climate change scenarios (Roughan \& Middleton 2004, Lough 2009, Ridgway \& Hill 2009). Many species have their northern or southern geographical range limits within this region (Knox 1963, O'Hara \& Poore 2000, Hidas et al. 2007, 2010, see also Ayre et al. 2009, Lathlean et al. 2010), and therefore, we might expect many of these species' range limits to shift with response to climate change. However, there is a significant gap in our understanding of the typical spatial and temporal temperature regimes experienced by intertidal organisms along the southeast coast of Australia, and researchers in the past have simply used satellite- or buoy-derived SST as a measure of large-scale temperature variability.

This study provides a detailed assessment of both large and small-scale in situ rocky intertidal temperature variability along the southeast coast of Australia. We first determined the extent to which nearshore SSTs derived from satellites and air temperatures derived from terrestrial weather stations can be used as appropriate surrogates of rocky intertidal water and air temperatures, respectively. We expected that water and air temperatures sensed remotely would be strongly correlated with values estimated using in situ loggers, but that absolute values would likely differ. We then show that small-scale (i.e. local) variability in air and water temperature, measured by in situ data loggers, better characterises the thermal environment experienced by intertidal organisms. Our objective here was to test whether temperature variability measured over both fine spatial (pairs of loggers separated by metres at 3 tidal heights) and fine temporal scales (10 min intervals) can reveal demographically important temperature variation that cannot be estimated using remote sensing.

\section{MATERIALS AND METHODS}

\section{Study region}

The study region spanned more than $400 \mathrm{~km}$ and included 4 rocky intertidal shores along the southeast coast of Australia: Garie Beach (34 ${ }^{\circ} 10^{\prime} 38.05^{\prime \prime} \mathrm{S}$, $\left.151^{\circ} 03^{\prime} 57.77^{\prime \prime} \mathrm{E}\right), \mathrm{Kiama}^{\circ}\left(34^{\circ} 40^{\prime} 07.47^{\prime \prime} \mathrm{S}, 150^{\circ} 51^{\prime} 25.66^{\prime \prime} \mathrm{E}\right)$, Bermagui ( $\left.36^{\circ} 25^{\prime} 35.64^{\prime \prime} \mathrm{S}, 150^{\circ} 05^{\prime} 01.84^{\prime \prime} \mathrm{E}\right)$ and Mallacoota (37³4' 39.87" S, $149^{\circ} 46^{\prime} 01.58^{\prime \prime}$ E; Fig. 1). Garie Beach and Bermagui had slightly sloping platforms 
$\left(10\right.$ to $\left.20^{\circ}\right)$, while Kiama and Mallacoota had steeper gradients $\left(20\right.$ to $\left.30^{\circ}\right)$. All locations experience a mixed semi-diurnal tidal regime with a tidal range of approximately $2 \mathrm{~m}$. Previous studies have shown that the degree of wave exposure can significantly influence temperature variability at a site (Harley \& Helmuth 2003, Fitzhenry et al. 2004, Denny et al. 2006); therefore, locations were chosen which have a north to northeast orientation, and all 4 experience similar levels of wave exposure (J. Lathlean pers. obs.). All locations support similar benthic communities within the mid-shore region largely dominated by the barnacles Tesseropora rosea and Catomerus polymerus, the gastropods Bembicium nanum, Nerita melanotragus and Morula marginalba, the limpets Cellana tramoserica and Patelloida latistrigata, and the macroalgae Hormosira banksii, Porphyra lucasii, P. columbina and Corallina officinalis (Underwood et al. 1983).

\section{In situ logger data}

To determine large-scale spatial variability in air and water temperatures among the 4 rocky shore locations, TidbiT ${ }^{\circledR}$ v2 Temp data loggers (Onset Stowaway logger, model UTBI-001, accuracy $\pm 0.2^{\circ} \mathrm{C}$ ) were deployed within the mid-intertidal zone $(0.8$ to $1 \mathrm{~m}$ above mean low water mark and 25 to $50 \mathrm{~cm}$ away from biota) at each of Garie Beach, Kiama, Bermagui and Mallacoota and continuously recorded both air and water temperatures at 10 min intervals from mid-April 2008 until June 2009. Loggers accu-

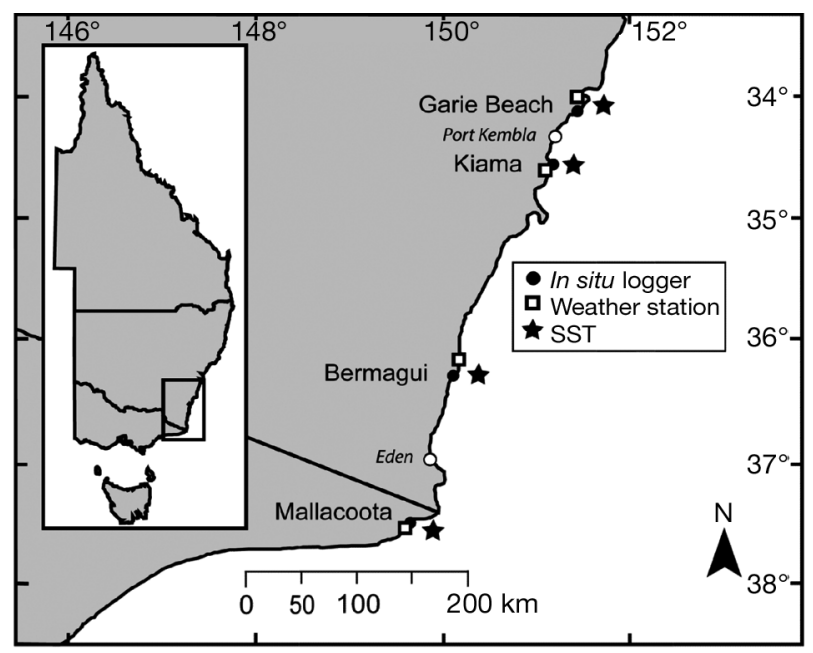

Fig. 1. Four rocky intertidal shores along the southeast coast of Australia showing approximate locations of in situ logger, weather station and satellite sea surface temperature (SST) collection points. Port Kembla and Eden represent locations where tidal data were obtained rately recorded temperatures within $\pm 0.2^{\circ} \mathrm{C}$. To assess temperature variability within a single location, additional loggers were deployed at 2 sites separated by approximately $50 \mathrm{~m}$ and across 3 intertidal heights within Garie Beach in February 2010. Air and sea surface temperature profiles between loggers at equivalent tidal heights were significantly correlated and produced average differences in air and water temperatures no greater than $2.6^{\circ} \mathrm{C}$ and $0.6^{\circ} \mathrm{C}$, respectively, over an extended period from February to September 2010 (see Fig. S1 and Table S1 in the Supplement at www.int-res.com/articles/suppl/m439 p083_supp.pdf). Denny et al. (2006) showed that intertidal temperatures can vary with differences in substrate aspect and orientation. Therefore, we took a conservative approach to estimating temperature variability by attaching all loggers to horizontal or slightly sloping rock surfaces with a north to northeast orientation.

To separate data logger temperatures into air and water temperatures, we used methods of estimating 'effective shore level' (ESL) similar to those of Harley \& Helmuth (2003). Here, a sudden drop in temperature by at least $3^{\circ} \mathrm{C}$ within 20 min during the daytime indicates when the logger is first inundated with the incoming tide. The time of this sudden drop is then matched with tidal heights recorded by buoys to give an ESL for each logger. Tidal data were obtained from either the Australian Bureau of Meteorology's National Tidal Centre (www.bom.gov.au/ oceanography/projects/ntc/ntc.shtml) or Manly Hydraulics Laboratory for buoys at Port Kembla $\left(34^{\circ} 29^{\prime} \mathrm{S}, 150^{\circ} 55^{\prime} \mathrm{E}\right)$, Bermagui $\left(36^{\circ} 25^{\prime} \mathrm{S}, 150^{\circ} 4^{\prime} \mathrm{E}\right)$ or Eden $\left(37^{\circ} 4^{\prime} \mathrm{S}, 149^{\circ} 54^{\prime} \mathrm{E}\right)$, and hourly temperature data recorded by loggers were compared with hourly tidal data recorded by the closest of these buoys (see Fig. 1). Temperatures that were recorded when the tidal height was below ESL values were deemed to be air temperatures, whereas temperatures recorded when the tidal height was above these values were deemed to be water temperatures. We applied a $0.3 \mathrm{~m}$ buffer zone above and below the ESL for each logger and excluded data that were obtained within this buffer zone because wave splash may also significantly influence whether a logger is submerged. This approach ensured that temperatures recorded during the changing of the tides accurately represent air or water temperatures. Once logger data were separated into air and water temperatures, daily mean, maxima and minima were calculated for both air and water temperatures at each of the 4 locations to characterise temporal and spatial temperature variability. Additionally, air and water temperature frequency distrib- 
utions were used to specifically compare temperature variability across the 4 locations.

\section{Satellite SST and terrestrial weather station data}

Comparisons were made between logger-derived in situ intertidal water temperatures and satellitederived SSTs at all 4 locations from 16 April 2008 to 6 June 2009. Satellite SST readings recorded twice every $24 \mathrm{~h}$ were obtained from the advanced very high resolution radiometer (AVHRR) taken from the NOAA series of polar orbiting satellites through the Integrated Marine Observing System web portal (www. marine.csiro.au/remotesensing/imos/aggregator.html). To standardise comparisons between in situ loggers and satellite-derived SSTs across the 4 locations, daily SST was acquired for single fixed pixels (representing an area of $\sim 2 \times 2 \mathrm{~km}$ ) approximately $7 \mathrm{~km}$ offshore for each of the 4 locations (Fig. 1). Choosing pixels $7 \mathrm{~km}$ offshore allowed standardised SST measurements among locations and maintained an equivalent offshore distance throughout the sampling region. Several single-day composites of SST were missing due to cloud cover at the time images were being taken by satellites, and therefore no comparisons could be made with in situ loggers on these days. Using these data, we correlated daily SST composites with daily mean water temperatures recorded by in situ temperature loggers within the mid-intertidal zone. Monthly maximum, minimum and mean satellite temperatures were also correlated with monthly maximum, minimum and mean logger temperatures to determine whether satellite SSTs were capable of detecting extreme temperature events that are often more biologically relevant than daily means (Denny et al. 2009).

Comparisons between air temperatures derived from in situ intertidal data loggers and terrestrial weather stations were also done for all 4 locations. Terrestrial weather station data were obtained from the Australian Bureau of Meteorology for coastal stations closest to the 4 study locations. Consequently, logger air temperatures recorded at Garie Beach, Kiama, Bermagui and Mallacoota were correlated with weather station air temperatures at Sydney Airport $(27.8 \mathrm{~km})$, Kiama Headland $(<0.5 \mathrm{~km})$, Narooma $(24.3 \mathrm{~km})$ and Mallacoota $(<0.5 \mathrm{~km})$, respectively (distances between loggers and weather stations shown in brackets). Each weather station recorded air temperatures every $3 \mathrm{~h}$, which allowed daily maximum, minimum and mean temperatures to be calculated and correlated with daily maximum, minimum and mean logger air temperatures.

\section{Biologically relevant temperature variation}

Demographic patterns of rocky intertidal invertebrates can often be significantly influenced by extreme temperature events, and invertebrates respond depending on the thermal characteristics leading up to and during the extreme temperature event (Denny et al. 2009, Mislan et al. 2009). Therefore, to further assess the ability of terrestrial weather stations to record biologically relevant estimates of rocky intertidal temperature, the number, duration and frequency of extreme temperature events recorded by in situ loggers at all 4 locations were compared with the same parameters recorded by nearby weather stations during the summer of 2008/09. Here, number refers to the number of days where air temperatures reached $30^{\circ} \mathrm{C}$, duration refers to the total time temperatures stayed at or above $30^{\circ} \mathrm{C}$, similar to degree heating hours (DHH) used by Helmuth et al. (2010), and frequency (expressed as its inverse) refers to the average time between $30^{\circ} \mathrm{C}$ events. These parameters were chosen based on findings of Denny et al. (2006, 2009), which showed that the number, duration and frequency of extreme temperature events are just as important as absolute temperatures when assessing how intertidal invertebrates respond to increased temperatures. Temperatures over $30^{\circ} \mathrm{C}$ were classified as extreme because previous studies have shown this temperature to be the approximate threshold for heat shock protein (Hsp) production in Mytilus spp. found at similar latitudes as in the present study (Halpin et al. 2004).

The rates at which temperatures rise and fall are also important parameters that can influence an organism's ability to respond to thermal stress. For intertidal organisms, the most rapid change in temperature is most likely to occur during the changing of the tides (Helmuth \& Hofmann 2001, Harley \& Helmuth 2003). Therefore, we used continuous in situ logger data (i.e. not separated into air and water temperatures) with 10 min sampling intervals to compare the frequency of rapid heating events measured by in situ loggers and the remote sensing methods at Garie Beach, Kiama and Bermagui during the summer of 2008/09. For in situ data, a rapid heating event was defined as either a rise of $15^{\circ} \mathrm{C}$ or more within $4 \mathrm{~h}, 10^{\circ} \mathrm{C}$ or more within $3 \mathrm{~h}$, or $5^{\circ} \mathrm{C}$ or more within 3 h. For equivalent comparisons to be made using remote sensing methods, a rapid heating event was defined as differences of 15,10 or $5^{\circ} \mathrm{C}$ between daily satellite SSTs and daily maximum air temperatures recorded by weather stations. These rates were somewhat arbitrarily defined based on the most extreme rate of heating (i.e. $18^{\circ} \mathrm{C}$ within $4 \mathrm{~h}$ ) being recorded by a logger at Garie Beach during the time of interest. 


\section{Data analysis}

Pearson's $r$ values were used to indicate the strength of the correlation between (1) logger water temperature and satellite SST, (2) logger air temperature and weather station air temperature and (3) loggers at 2 sites within Garie Beach across the 3 different intertidal heights with differences being tested with paired $t$-tests. Correlations and paired $t$-tests could only be undertaken for approximately 9 mo at Mallacoota because the logger was damaged.

A 2-way ANOVA using log $(x+1)$ transformed data was used to test for statistically significant differences in daily means, maxima and minima of air and water temperatures across 3 of the rocky shore locations (from June 2008 to May 2009; Mallacoota was excluded from ANOVA due to incomplete data), and time. Where significant differences were found, Stu-
dent-Neuman-Keuls (SNK) tests were used to determine which locations or seasons had significantly different temperatures. Due to natural variability in weather and the tidal cycle, some loggers appeared to remain either emerged or submerged for more than $24 \mathrm{~h}$. Consequently, several days during the sampling period did not record either air and water temperatures and were therefore excluded from analysis.

\section{RESULTS}

\section{Comparisons of temperature variability at geographic scales}

Air temperatures generally declined with increasing latitude (Tables $1 \& 2$ ). For example, mean $\pm \mathrm{SD}$ daily maximum in situ air temperatures, averaged

Table 1. Seasonal and annual variation in daily mean, maximum and minimum air and water temperatures $( \pm$ SD) from in situ temperature data loggers within the mid-intertidal zone at the 4 study locations between June 2008 and May 2009. Max/Min represents the highest and lowest temperatures recorded at each location during a specific season

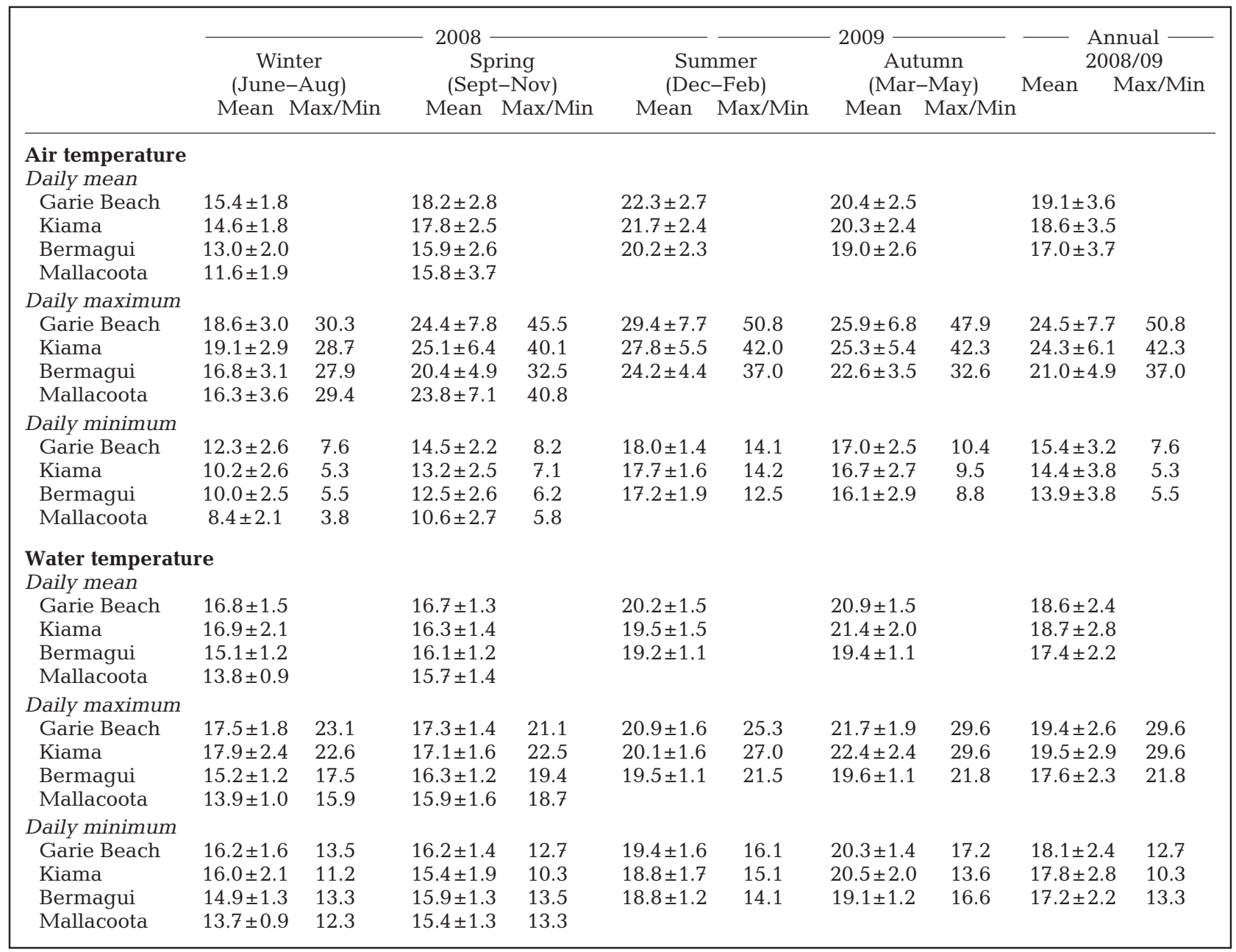


Table 2. Results of ANOVA for the differences in daily mean, maximum and minimum air and water temperatures (log $[\mathrm{x}+1]$ transformed) among 3 locations across 4 seasons. Data from Mallacoota were only available until 10 December 2008 and therefore not included in the analysis

\begin{tabular}{|c|c|c|c|c|}
\hline Source & $\mathrm{df}$ & SS & $F$ & $\mathrm{p}$ \\
\hline \multicolumn{5}{|l|}{ Air temperature } \\
\hline \multicolumn{5}{|l|}{ Daily mean } \\
\hline Location & 2 & 2.65 & 85.01 & $<0.0001$ \\
\hline Season & 3 & 23.28 & 497.91 & $<0.0001$ \\
\hline Location $\times$ Season & 6 & 0.24 & 2.59 & 0.0170 \\
\hline Error & 1068 & 16.65 & & \\
\hline \multicolumn{5}{|l|}{ Daily maximum } \\
\hline Location & 2 & 4.57 & 55.20 & $<0.0001$ \\
\hline Season & 3 & 20.92 & 168.28 & $<0.0001$ \\
\hline Location $\times$ Season & 6 & 0.35 & 1.40 & 0.2108 \\
\hline Error & 1068 & 44.25 & & \\
\hline \multicolumn{5}{|l|}{ Daily minimum } \\
\hline Location & 2 & 2.35 & 40.17 & $<0.0001$ \\
\hline Season & 3 & 38.39 & 433.42 & $<0.0001$ \\
\hline Location $\times$ Season & 6 & 0.96 & 5.46 & $<0.0001$ \\
\hline Error & 1068 & 31.21 & & \\
\hline \multicolumn{5}{|l|}{ Water temperature } \\
\hline \multicolumn{5}{|l|}{ Daily mean } \\
\hline Location & 2 & 0.66 & 53.17 & $<0.0001$ \\
\hline Season & 3 & 9.89 & 442.87 & $<0.0001$ \\
\hline Location $\times$ Season & 6 & 0.29 & 7.09 & $<0.0001$ \\
\hline Error & 805 & 4.97 & & \\
\hline \multicolumn{5}{|l|}{ Daily maximum } \\
\hline Location & 2 & 1.40 & 99.29 & $<0.0001$ \\
\hline Season & 3 & 7.73 & 364.93 & $<0.0001$ \\
\hline Location $\times$ Season & 6 & 0.35 & 8.36 & $<0.0001$ \\
\hline Error & 805 & 5.69 & & \\
\hline \multicolumn{5}{|l|}{ Daily minimum } \\
\hline Location & 2 & 0.21 & 13.88 & $<0.0001$ \\
\hline Season & 3 & 8.55 & 368.83 & $<0.0001$ \\
\hline Location $\times$ Season & 6 & 0.23 & 4.88 & $<0.0001$ \\
\hline Error & 805 & 6.22 & & \\
\hline
\end{tabular}

over the 12 mo sampling period, were $24.5 \pm 7.7,24.3$ \pm 6.1 and $21.0 \pm 4.9^{\circ} \mathrm{C}$ at Garie Beach, Kiama and Bermagui, respectively (Table 1 ), with maximum air temperatures of $50.0,42.3$ and $37.0^{\circ} \mathrm{C}$ at Garie Beach, Kiama and Bermagui, respectively (Table 1). Air temperatures recorded by in situ loggers also varied consistently with latitude when seasons were analyzed separately (SNK test for interactions, see Table 2). Daily maximum air temperatures recorded by weather stations averaged for the 12 mo sampling period were $21.5 \pm 4.9,20.0 \pm 3.9,18.4 \pm 3.4$ and $18.1 \pm 4.5^{\circ} \mathrm{C}$ at Garie Beach, Kiama, Bermagui and Mallacoota, respectively, with maximum air temperatures of $38.3,37.5,33$ and $38.4^{\circ} \mathrm{C}$, respectively. In situ logger air temperatures were highly variable across all 4 locations from June to November 2008, suggesting that air temperature variability does not vary with latitude (Fig. 2).
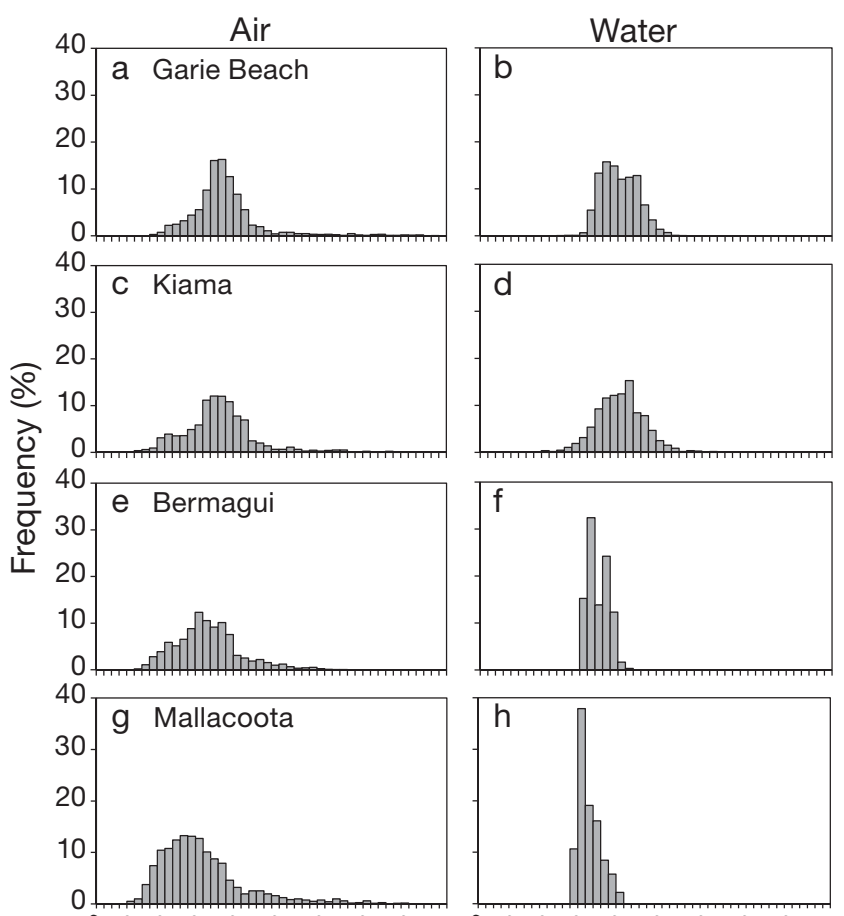

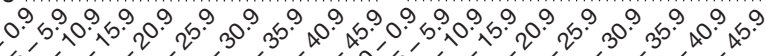

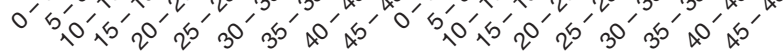

Temperature $\left({ }^{\circ} \mathrm{C}\right)$

Fig. 2. In situ logger air and water temperature frequency distributions at the 4 study locations from 1 June to 30 November 2008. Locations are arranged from north to south

In contrast to air temperatures, in situ loggers only recorded a weak latitudinal decline in water temperatures, with loggers at Garie Beach and Kiama, separated by approximately $60 \mathrm{~km}$, recording similar intertidal water temperatures that were both significantly different from intertidal water temperatures recorded at Bermagui, which is approximately $210 \mathrm{~km}$ south of Kiama (Fig. 3, Table 2). For example, the annual daily mean water temperatures recorded by in situ data loggers at Garie Beach, Kiama and Bermagui were $18.7 \pm 2.4,18.7 \pm 2.8$ and $17.4 \pm 2.2^{\circ} \mathrm{C}$, respectively (Table 2). However, intertidal water temperatures appeared to be consistently more variable at Garie Beach and Kiama than they were at Bermagui and Mallacoota, and this was not detected by satellite SST data (Figs. $2 \& 3$ ).

\section{Satellite versus in situ logger water temperatures}

Comparison of SST and in situ logger estimates of water temperature revealed that although the 2 sets of measures were always significantly correlated, they typically produced significantly different esti- 

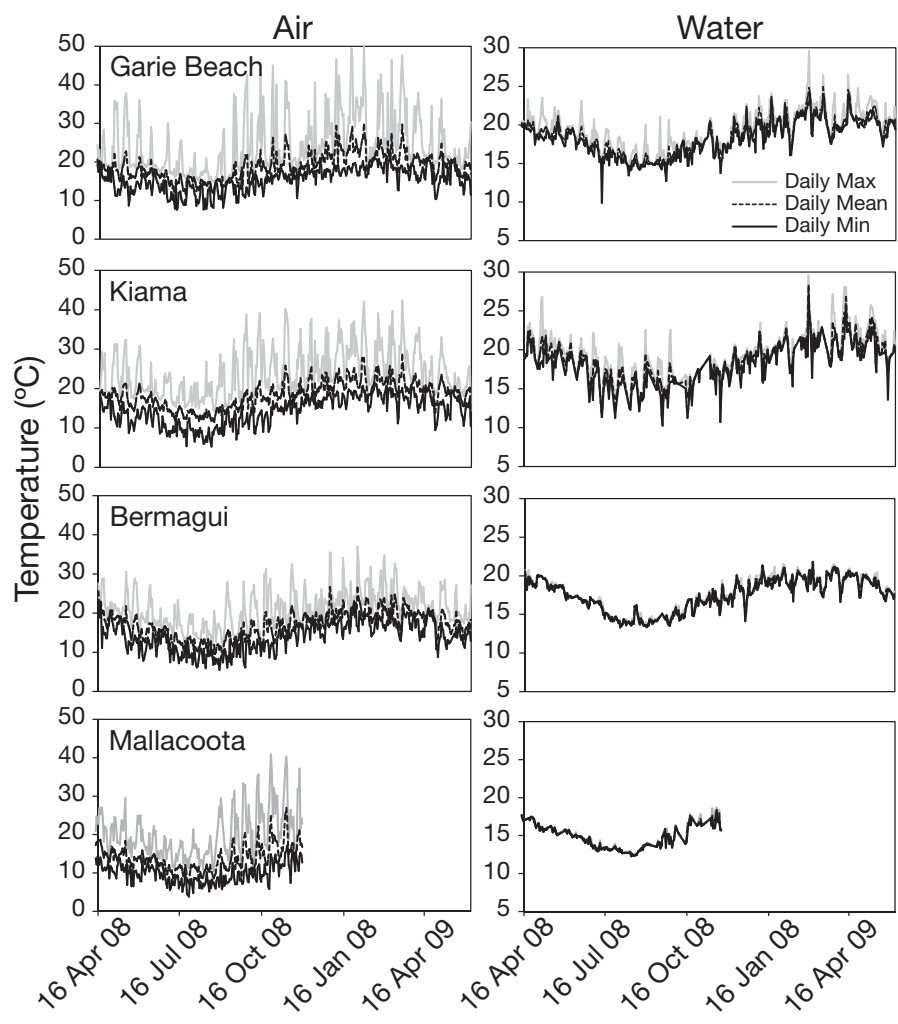

Fig. 3. Daily mean, maximum and minimum air and water temperatures recorded by in situ data loggers at the 4 study locations from 16 April 2008 to 6 June 2009 (Mallacoota data were only available until 10 December 2008). Note different scales on $y$-axes

mates of absolute temperatures. For example, at all 4 study locations, daily satellite SSTs $7 \mathrm{~km}$ offshore were significantly correlated with daily mean water temperatures recorded by in situ loggers within the mid-intertidal zone, although the correlation coefficient varied substantially among locations, ranging from 0.50 at Kiama to 0.77 at Bermagui (Fig. 4, Table 3). Similarly, means, maxima and minima of monthly satellite SSTs were significantly correlated with water temperatures estimated by intertidal loggers, except for the most southerly location, Mallacoota (Fig. 4, Table 3). The strength of correlations between monthly measurements varied considerably more among locations than correlations between daily means (Table 3 ).

Although daily satellite SSTs and daily logger water temperatures were strongly correlated, absolute estimates of water temperature were significantly different from each other, with the exception of temperatures recorded at Mallacoota (Table 3). Daily satellite SSTs were generally greater than logger water temperatures, with maximum differences at times reaching $6.7^{\circ} \mathrm{C}$, but on average these differ-
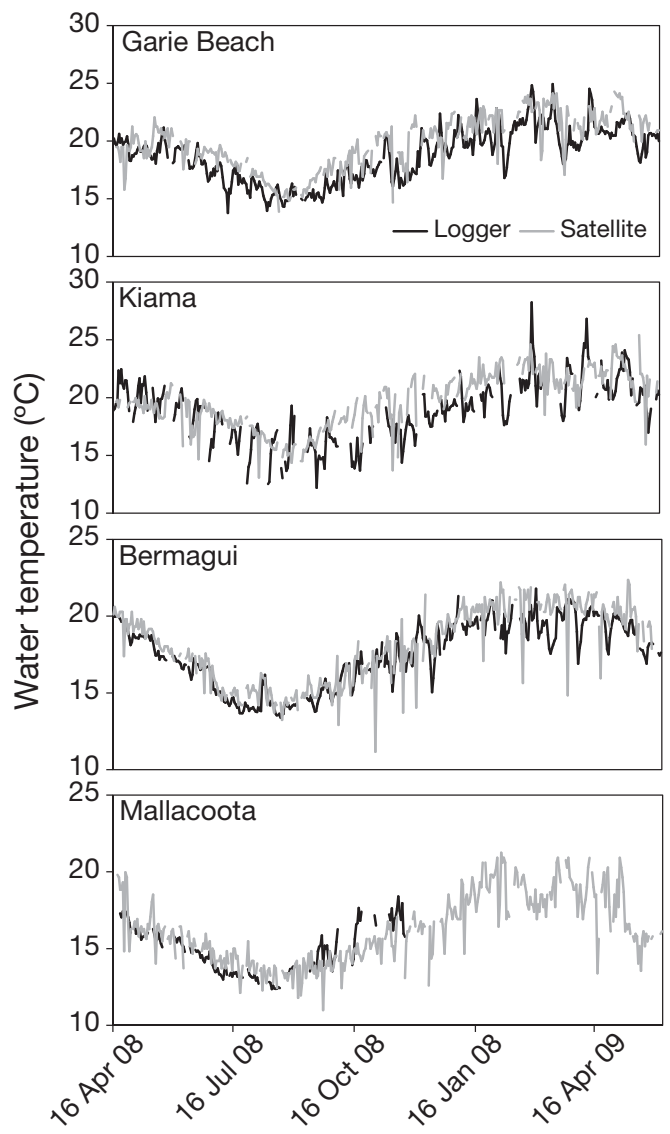

Fig. 4. Daily mean water temperatures from in situ loggers within the mid-intertidal zone at each of the 4 study locations and satellite-derived SSTs approximately $7 \mathrm{~km}$ offshore of each of the 4 study locations from 16 April 2008 to 6 June 2009 (Mallacoota data were only available until 10 December 2008). Note different scales on $y$-axes for Bermagui and Mallacoota

ences were less than $\sim 1^{\circ} \mathrm{C}$ across all 4 locations and decreased with increasing latitude (Fig. 4, Table 3). Paired $t$-tests also revealed that loggers often recorded significantly higher monthly mean, maximum and minimum temperatures compared to satellites, with maximum and mean differences reaching $6^{\circ} \mathrm{C}$ and $1.3^{\circ} \mathrm{C}$, respectively (Table 1 ).

\section{Weather station versus in situ logger air temperature}

At all 4 locations, daily means, maxima and minima of air temperature recorded by in situ loggers and weather stations were all significantly correlated (Fig. 5, Table 4), although these correlations were substantially weaker than those between daily satellite SSTs and intertidal water temperatures 
Table 3. Outcome summary of paired $t$-tests and Pearson correlations comparing daily means and monthly means, maxima and minima of water temperatures, derived from in situ loggers within the mid-intertidal zone at the 4 study locations with satellite-derived SSTs approximately $7 \mathrm{~km}$ offshore of each location from 16 April 2008 to 6 June 2009 (see Fig. 3). Mallacoota data were only available until 10 December 2008. Mean and max. difference refers to the average and maximum differences between water temperatures measured by in situ loggers and satellites. ${ }^{*} \mathrm{p}<0.001,{ }^{* *} \mathrm{p}<0.05$

\begin{tabular}{|c|c|c|c|c|c|c|}
\hline & \multirow[t]{2}{*}{ df } & \multicolumn{2}{|c|}{ Difference $\left({ }^{\circ} \mathrm{C}\right)$} & \multirow[t]{2}{*}{$t$} & \multirow[t]{2}{*}{$\mathrm{p}$} & \multirow{2}{*}{$\begin{array}{l}\text { Pearson's } \\
\text { correlation (r) }\end{array}$} \\
\hline & & Mean & Max. & & & \\
\hline \multicolumn{7}{|l|}{ Daily means } \\
\hline Garie Beach & 363 & 1.03 & 4.98 & 13.55 & $<0.001$ & $0.64^{*}$ \\
\hline Kiama & 266 & 0.81 & 6.67 & 6.75 & $<0.001$ & $0.50^{*}$ \\
\hline Bermagui & 341 & 0.64 & 6.24 & 10.07 & $<0.001$ & $0.77^{*}$ \\
\hline Mallacoota & 147 & 0.04 & 3.20 & 0.40 & 0.655 & $0.58^{*}$ \\
\hline \multicolumn{7}{|l|}{ Monthly means } \\
\hline Garie Beach & 12 & 1.19 & 1.80 & 10.95 & $<0.001$ & $0.97^{*}$ \\
\hline Kiama & 12 & 1.05 & 2.68 & 3.61 & 0.004 & $0.80^{*}$ \\
\hline Bermagui & 12 & 0.59 & 1.28 & 5.50 & $<0.001$ & $0.98^{*}$ \\
\hline Mallacoota & 6 & 0.20 & 1.31 & 0.59 & 0.578 & $0.63^{*}$ \\
\hline \multicolumn{7}{|c|}{ Monthly maxima } \\
\hline Garie Beach & 12 & 0.49 & 1.90 & 1.73 & 0.110 & $0.89^{*}$ \\
\hline Kiama & 12 & 0.05 & 4.44 & 0.08 & 0.941 & $0.55^{* *}$ \\
\hline Bermagui & 12 & 0.78 & 2.20 & 4.44 & 0.001 & $0.93^{*}$ \\
\hline Mallacoota & 6 & 0.06 & 1.90 & 1.06 & 0.919 & 0.41 \\
\hline \multicolumn{7}{|c|}{ Monthly minima } \\
\hline Garie Beach & 12 & 0.63 & 3.15 & 1.94 & 0.077 & $0.68^{*}$ \\
\hline Kiama & 12 & 1.29 & 6.03 & 2.51 & 0.027 & $0.53^{* *}$ \\
\hline Bermagui & 12 & 1.02 & 2.72 & 2.68 & 0.020 & $0.52^{* *}$ \\
\hline Mallacoota & 6 & 1.26 & 2.70 & 3.33 & 0.016 & 0.36 \\
\hline
\end{tabular}

Table 4. Outcome summary of paired $t$-tests and Pearson correlations comparing daily means, maxima and minima of air temperatures derived from in situ loggers within the mid-intertidal zone at the 4 study locations with air temperatures obtained by terrestrial weather stations no more than $28 \mathrm{~km}$ away from 16 April 2008 to 6 June 2009 (see Fig. 4). Mallacoota data were only available until 10 December 2008. Mean and max. difference refers to the average and maximum differences between air temperatures measured by in situ loggers and weather stations. ${ }^{*} \mathrm{p}<0.001$

\begin{tabular}{|lrrrrrr|}
\hline & df & $\begin{array}{c}\text { Difference }\left({ }^{\circ} \mathrm{C}\right) \\
\text { Mean }\end{array}$ & \multicolumn{1}{c}{$t$} & $\mathrm{p}$ & $\begin{array}{c}\text { Pearson's } \\
\text { correlation }(\mathrm{r})\end{array}$ \\
\hline $\begin{array}{l}\text { Daily means } \\
\text { Garie Beach }\end{array}$ & 416 & 1.02 & 9.56 & 7.84 & $<0.0001$ & $0.60^{*}$ \\
Kiama & 416 & 1.47 & 7.44 & 13.69 & $<0.0001$ & $0.62^{*}$ \\
Bermagui & 410 & 0.08 & 19.20 & 0.73 & 0.4671 & $0.60^{*}$ \\
Mallacoota & 228 & 1.53 & 7.71 & 12.41 & $<0.0001$ & $0.69^{*}$ \\
Daily maximum & & & & & & \\
$\quad$ Garie Beach & 416 & 2.98 & 23.19 & 10.34 & $<0.0001$ & $0.39^{*}$ \\
Kiama & 416 & 4.23 & 18.77 & 16.70 & $<0.0001$ & $0.27^{*}$ \\
Bermagui & 410 & 2.59 & 21.00 & 12.46 & $<0.0001$ & $0.26^{*}$ \\
Mallacoota & 228 & 3.90 & 18.17 & 12.82 & $<0.0001$ & $0.49^{*}$ \\
Daily minimum & & & & & & \\
Garie Beach & 416 & 0.73 & 10.32 & 5.02 & $<0.0001$ & $0.54^{*}$ \\
Kiama & 416 & 0.10 & 7.42 & 1.11 & 0.2688 & $0.73^{*}$ \\
Bermagui & 410 & 1.50 & 18.40 & 12.53 & $<0.0001$ & $0.61^{*}$ \\
Mallacoota & 228 & 1.03 & 8.30 & 10.72 & $<0.0001$ & $0.76^{*}$ \\
\hline
\end{tabular}

(cf. Tables $3 \& 4$ ). With the exception of minimum and mean air temperatures at Kiama and Bermagui, respectively, in situ loggers consistently recorded significantly higher daily air temperatures than weather stations (Fig. 5), with differences most pronounced for daily maximum air temperatures (Table 4). For example, across the 4 locations, daily maximum air temperatures recorded by in situ loggers were on average 2.6 to $4.2^{\circ} \mathrm{C}$ higher than daily maximum air temperatures recorded by weather stations (Fig. 5, Table 4). In contrast, daily minimum air temperatures recorded by in situ loggers were on average only 0.1 to $1.5^{\circ} \mathrm{C}$ higher than daily minimum air temperatures recorded by weather stations. Maximum differences in mean, maximum, and minimum air temperatures recorded by in situ loggers and weather stations were 19.2, 23.2 and $18.4^{\circ} \mathrm{C}$, respectively, which are considerably greater than similar comparisons of in situ logger water temperatures and satellite SSTs (cf. Tables $3 \& 4$ ).

\section{Biologically relevant temperature variation}

Regardless of latitude, in situ loggers recorded a considerably greater number, frequency and duration of extreme temperature events compared to nearby weather stations (Table 5). For example, the in situ logger at Garie Beach recorded 29 and 44 days where temperatures reached 35 and $30^{\circ} \mathrm{C}$, respectively; in comparison, weather stations detected only 2 and 19 days reaching 35 and $30^{\circ} \mathrm{C}$, respectively. The number, frequency and duration of extreme temperature events also increased with decreasing latitude, indicating that northern locations may be more thermally stressful for intertidal invertebrates. For example, the number of days where temperatures reached $35^{\circ} \mathrm{C}$ decreased 

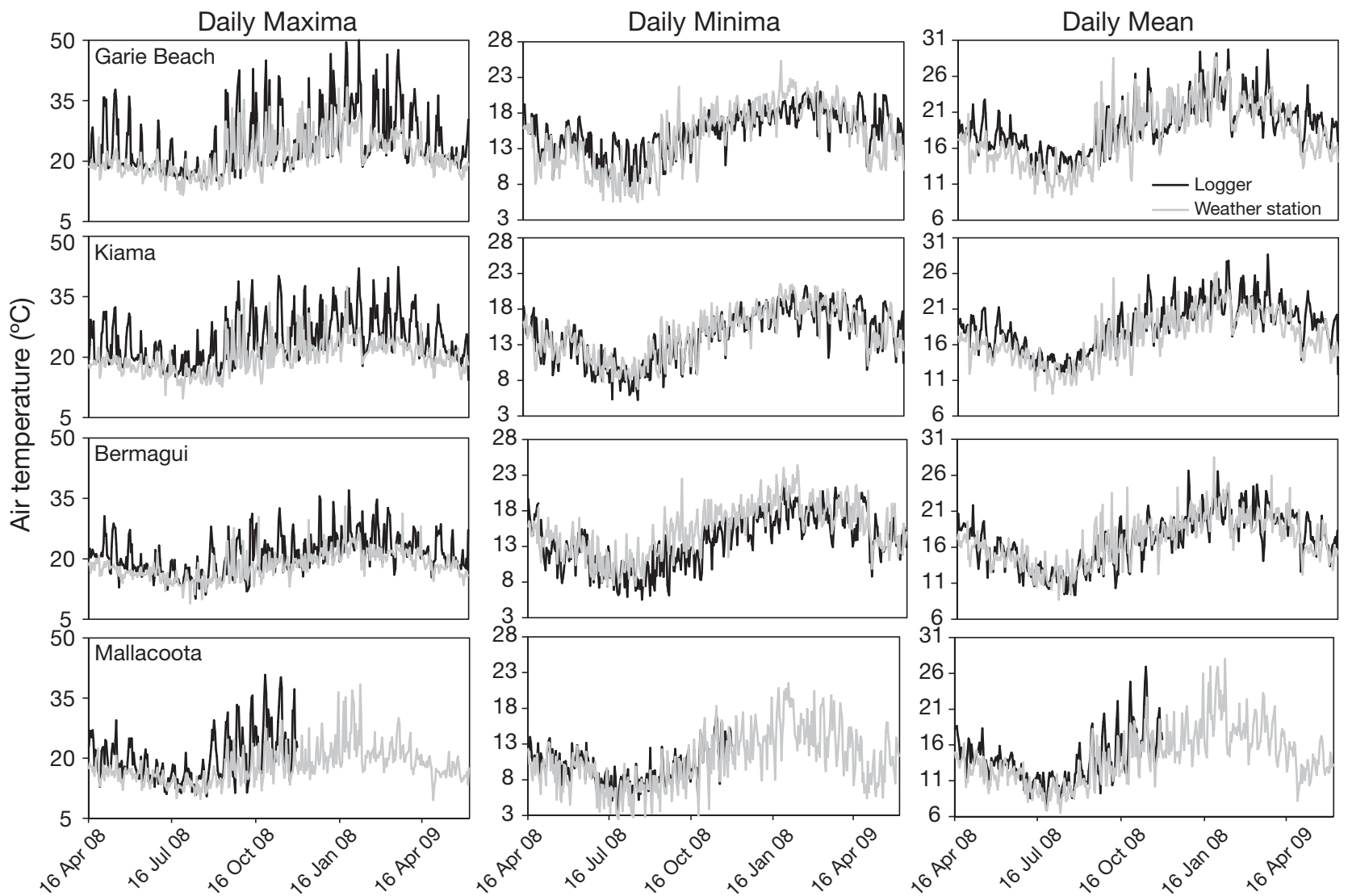

Fig. 5. Daily air temperatures from in situ loggers within the mid-intertidal zone and weather station temperatures at each of the 4 study locations from 16 April 2008 to 6 June 2009 (Mallacoota data were only available until 10 December 2008). Note different scales on $y$-axes

Table 5. Comparison of biologically important temperature parameters measured by an in situ data logger within the mid-intertidal zone at Garie Beach, Kiama and Bermagui with nearby terrestrial weather stations during the summer of $2008 / 09.30^{\circ} \mathrm{C}$ temperature events were classified as any day where air temperatures reached $30^{\circ} \mathrm{C}$. Data from Mallacoota were only available until 10 December 2008 and therefore not included in the analysis

\begin{tabular}{|lcccc|}
\hline & $\begin{array}{c}\text { No. days } \\
\text { max. temp } \\
>35^{\circ} \mathrm{C}>30^{\circ} \mathrm{C}\end{array}$ & $\begin{array}{c}\text { Duration } \\
\left(\text { h above } 30^{\circ} \mathrm{C} \text { ) }\right.\end{array}$ & $\begin{array}{c}\text { Frequency } \\
\text { (average time } \\
\text { between } 30^{\circ} \mathrm{C} \\
\text { events, } \mathrm{h} \pm \mathrm{SD} \text { ) }\end{array}$ \\
\hline $\begin{array}{l}\text { Garie Beach } \\
\text { In situ data logger }\end{array}$ & 29 & 44 & 111 & $42.8 \pm 55.7$ \\
$\quad$ Weather station & 2 & 19 & 105 & $86.3 \pm 99.6$ \\
$\begin{array}{l}\text { Kiama } \\
\quad \text { In situ data logger }\end{array}$ & 15 & 44 & 95 & $43.2 \pm 45.9$ \\
$\quad$ Weather station & 1 & 6 & 24 & $255 \pm 206.6$ \\
$\begin{array}{l}\text { Bermagui } \\
\text { In situ data logger }\end{array}$ & 3 & 17 & 29 & $123.1 \pm 105$ \\
$\quad$ Weather station & 0 & 1 & 3 & - \\
\hline
\end{tabular}

from 29 to 15 to 3 and the total number of hours spent above $30^{\circ} \mathrm{C}$ decreased from 111 to 95 to 29 at Garie Beach, Kiama and Bermagui, respectively. In situ loggers also recorded a considerably greater number of rapid heating events compared to those recorded by weather stations and satellites across all locations (Table 6). For example, at Garie Beach the in situ logger recorded 24 days where temperatures increased by over $15^{\circ} \mathrm{C}$ within $4 \mathrm{~h}$, whereas weather stations and satellites only recorded 2. Logger data revealed that heating rates also varied with latitude (Table 6). For example, the number of days where temperatures increased by more than $15^{\circ} \mathrm{C}$ within $4 \mathrm{~h}$ decreased from 24 to 10 to 5 at Garie Beach, Kiama and Bermagui, respectively. 
Table 6. Number of rapid heating events recorded by in situ data loggers and remote sensing devices among 3 of the study locations during the summer of $2008 / 09$. Heating rates were determined by the difference in daily SSTs and daily maximum air temperatures recorded by weather stations. Data from Mallacoota were only available until 10 December 2008 and therefore were not included in the analysis

\begin{tabular}{|c|c|c|c|}
\hline & \multicolumn{3}{|c|}{$\begin{array}{l}\text { No. days when temp. increased by more than } \\
15^{\circ} \mathrm{C} \text { within } 4 \mathrm{~h} \quad 10^{\circ} \mathrm{C} \text { within } 3 \mathrm{~h} \quad 5^{\circ} \mathrm{C} \text { within } 3\end{array}$} \\
\hline \multicolumn{4}{|l|}{ Garie Beach } \\
\hline In situ data logger & 24 & 40 & 62 \\
\hline Weather station and satellite & 2 & 15 & 45 \\
\hline \multicolumn{4}{|l|}{ Kiama } \\
\hline In situ data logger & 10 & 34 & 74 \\
\hline Weather station and satellite & 1 & 5 & 12 \\
\hline \multicolumn{4}{|l|}{ Bermagui } \\
\hline In situ data logger & 5 & 16 & 50 \\
\hline Weather station and satellite & 0 & 2 & 11 \\
\hline
\end{tabular}

unexpected lack of correlation with latitude most likely reflects differences among sites with respect to wave exposure (Harley \& Helmuth 2003, Fitzhenry et al. 2004, Davenport \& Davenport 2005), even though wave exposure was subjectively quantified and standardised by choosing locations with similar aspects. Indeed, Jackson (2010) demonstrated that the degree of wave exposure on rocky intertidal shores influences air temperatures within crevices. However, further research is needed to understand the role of wave exposure on latitudinal patterns of intertidal air temperature within this region.

\section{DISCUSSION}

The strong correlations that we detected between daily or monthly temporal variation in temperatures estimated by both satellite and weather station data and in situ intertidal temperature loggers provides superficial validation of the use of remote sensing to characterise the intertidal environment. However, even estimating variation at these coarse scales, remotely sensed and in situ estimates of air and water temperature at times differed by up to 23.2 and $6.7^{\circ} \mathrm{C}$, respectively. Our results also show that the use of satellites and weather stations as proxies of intertidal temperatures significantly underestimate biologically important extreme temperature events.

\section{Temperature variability at geographic scales}

Excluding the most southern location, in situ temperature variability among locations was shown to be highly variable, with average air and water temperatures generally declining with latitude. However, in situ air temperatures recorded at Mallacoota, the most southern location, appeared greater and more variable than temperatures recorded at Bermagui, suggesting that intertidal air temperatures along the southeast coast of Australia may not necessarily decline with increasing latitude.

Helmuth et al. (2006) similarly reported that among-site variation in the body temperatures of mussels were not well correlated with latitude. This

\section{Satellite and weather station data versus logger data}

The results of this study show that, although strongly correlated, in situ intertidal water temperatures are significantly different than those estimated by satellites, with in situ loggers generally recording lower water temperatures than satellites. This strong correlation between satellite SST and intertidal water temperature supports an equivalent study undertaken within the subtidal, where nearshore benthic water temperatures and satellite-derived SSTs were highly correlated to, yet 1 to $2^{\circ} \mathrm{C}$ lower than, satellite SSTs within temperate regions of Western Australia (Smale \& Wernberg 2009). As we observed when comparing in situ and satellite water temperatures, air temperatures recorded by in situ loggers and weather stations were both strongly correlated and significantly different. Nonetheless, correlations between weather stations and loggers were considerably weaker than correlations between satellites and loggers, and in situ air temperatures were generally warmer than weather station air temperatures. The consistently higher air temperatures recorded by in situ loggers may reflect differences in microclimates. For example, in situ loggers in the present study were exposed to full UV light, while weather station temperature readings were taken within shaded housings (information from the Australian Bureau of Meteorology, www.bom.gov.au).

Importantly, our study showed that the effectiveness of satellite-derived SSTs and weather station air temperatures as proxies of intertidal water and air temperatures varied across geographic locations. 
This geographic variation in the accuracy of satellite SSTs in estimating intertidal water temperatures may reflect differences in nearshore water circulation across the 4 study locations. For instance, at large spatial scales, SSTs in this region are mostly influenced by large warm-core eddies that move in a counter-clockwise direction from north to south (Huyer et al. 1988, Roughan \& Middleton 2002, 2004). However, at relatively small spatial scales, the movement of nearshore water may also be influenced by subtidal topography, including islands (see Mace \& Morgan 2006), and localised atmospheric conditions. Therefore, the association between intertidal and offshore water temperatures may vary among locations because offshore water may not always move shoreward.

The effectiveness of weather stations as estimates of intertidal air temperatures also varied among locations. Surprisingly, however, correlations between weather stations and in situ loggers at Kiama and Mallacoota, where loggers were located within several hundred metres of weather stations, were no stronger than correlations for Garie Beach and Bermagui, where loggers were up to $28 \mathrm{~km}$ from weather stations. This suggests that the value of weather station data as surrogates for values estimated by in situ loggers could not be improved by standardised usage of weather stations in close proximity to rocky shores of interest.

\section{Biologically relevant temperature variability}

The physiological performance of many marine and terrestrial organisms has long been understood to be strongly influenced by short-term extremes and rapid fluctuations in temperature. Consequently, thermal limits are often used to estimate the vulnerability of a particular species to in situ heat stress (Denny et al. 2006, Dong et al. 2008). Our results show that weather station data are unlikely to detect acute changes in intertidal air temperatures or accurately characterise temperature extremes relevant to organisms. Since air temperatures are believed to play a significant role in the physiological processes of intertidal organisms (Schiel et al. 2004), this is a major discrepancy that may have important implications when using weather station data to model past and future effects of temperature variability on species distributions and range limits. For instance, Denny et al. (2006) used weather station data to create a model of predicted body temperatures for the intertidal limpet Lottia gigantea and found that over a 5 yr period, body temperatures only reached lethal limits $\left(34-38^{\circ} \mathrm{C}\right)$ on 3 days. Our results would suggest that this might be a serious underestimation of extreme intertidal temperature events.

Mortality caused by heat stress depends not only on the frequency of high temperature events but also on the rate of heating and cooling experienced by organisms (Denny et al. 2006), which in the absence of behavioural avoidance will be determined by the timing of low tides, the degree of wave exposure and weather (Harley \& Helmuth 2003, Harley 2008, Mislan et al. 2009). In the present study, we have shown that satellite SSTs and weather station air temperatures are unlikely to detect the majority of rapid heating events within the mid-intertidal zone. Therefore, we argue that attempts to predict the effect of temperature change on intertidal taxa require in situ measurements and should focus on biologically relevant variation.

Acknowledgements. We thank R. McWilliam, L. Aguilar and A. Swan for assistance in the field. This research was supported under the ARC 'Discovery Project' funding scheme (project no. DP0666787) through a grant to D.J.A. and T.E.M., a University of Wollongong post-graduate scholarship to J.A.L. and by the Institute for Conservation Biology at the University of Wollongong.

\section{LITERATURE CITED}

Ayre DJ, Minchinton TE, Perrin C (2009) Does life history predict past and current connectivity for rocky intertidal invertebrates across a marine biogeographic barrier? Mol Ecol 18:1887-1903

> Barry JP, Baxter CH, Sagarin RD, Gilman SE (1995) Climaterelated, long-term faunal changes in a California rocky intertidal community. Science 267:672-675

> Barton I, Pearce A (2006) Validation of GLI and other satellite-derived sea surface temperatures using data from the Rottnest Island ferry, Western Australia. J Oceanogr 62:303-310

> Blanchette CA, Miner CM, Raimondi PT, Lohse D, Heady KEK, Broitman BR (2008) Biogeographical patterns of rocky intertidal communities along the Pacific coast of North America. J Biogeogr 35:1593-1607

Broitman BR, Navarrete SA, Smith F, Gaines SD (2001) Geographic variation of southeastern Pacific intertidal communities. Mar Ecol Prog Ser 224:21-34

Broitman BR, Blanchette CA, Gaines SD (2005) Recruitment of intertidal invertebrates and oceanographic variability at Santa Cruz Island, California. Limnol Oceanogr 50: 1473-1475

> Broitman BR, Blanchette CA, Menge BA, Lubchenco J and others (2008) Spatial and temporal patterns of invertebrate recruitment along the west coast of the United States. Ecol Monogr 78:403-421

Davenport J, Davenport JL (2005) Effects of shore height, wave exposure and geographical distance on thermal niche width of intertidal fauna. Mar Ecol Prog Ser 292: $41-50$ 
Denny MW, Miller LP, Harley CDG (2006) Thermal stress on intertidal limpets: long-term hindcasts and lethal limits. J Exp Biol 209:2420-2431

Denny MW, Hunt LJH, Miller LP, Harley CDG (2009) On the prediction of extreme ecological events. Ecol Monogr 79: 397-421

> Dong Y, Miller LP, Sanders JG, Somero GN (2008) Heatshock protein 70 (hsp70) expression in four limpets of the genus Lottia: interspecific variation in constitutive and inducible synthesis correlates with in situ exposure to heat stress. Biol Bull (Woods Hole) 215:173-181

Edgar GJ (2008) Australian marine life: the plants and animals of temperate waters, 2nd edn. New Holland, Sydney

Fields PA, Graham JB, Rosenblatt RH, Somero GN (1993) Effects of expected global climate-change on marine faunas. Trends Ecol Evol 8:361-367

> Fitzhenry T, Halpin PM, Helmuth B (2004) Testing the effects of wave exposure, site, and behavior on intertidal mussel body temperatures: applications and limits of temperature logger design. Mar Biol 145:339-349

Gilman SE (2006) Life at the edge: an experimental study of a poleward range boundary. Oecologia 148:270-279

Gilman SE, Wethey DS, Helmuth B (2006) Variation in the sensitivity of organismal body temperature to climate change over local and geographic scales. Proc Natl Acad Sci USA 103:9560-9565

> Halpin PM, Menge BA, Hofmann GE (2004) Experimental demonstration of plasticity in the heat shock response of the intertidal mussel Mytilus californianus. Mar Ecol Prog Ser 276:137-145

> Harley CDG (2008) Tidal dynamics, topographic orientation, and temperature-mediated mass mortalities on rocky shores. Mar Ecol Prog Ser 371:37-46

> Harley CDG, Helmuth BST (2003) Local- and regional-scale effects of wave exposure, thermal stress, and absolute versus effective shore level on patterns of intertidal zonation. Limnol Oceanogr 48:1498-1508

Harley CDG, Paine RT (2009) Contingencies and compounded rare perturbations dictate sudden distributional shifts during periods of gradual climate change. Proc Natl Acad Sci USA 106:11172-11176

> Helmuth B (2009) From cells to coastlines: How can we use physiology to forecast the impacts of climate change? J Exp Biol 212:753-760

> Helmuth B, Hofmann GE (2001) Microhabitats, thermal heterogeneity, and patterns of physiological stress in the rocky intertidal zone. Biol Bull (Woods Hole) 201: 374-384

Helmuth B, Harley CDG, Halpin PM, O'Donnell M, Hofmann GE, Blanchette CA (2002) Climate change and latitudinal patterns of intertidal thermal stress. Science 298: 1015-1017

Helmuth B, Broitman BR, Blanchette CA, Gilman SE and others (2006) Mosaic patterns of thermal stress in the rocky intertidal zone: implications for climate change. Ecol Monogr 76:461-479

> Helmuth B, Broitman BR, Yamane L, Gilman SE, Mach K, Mislan KAS, Denny MW (2010) Organismal climatology: analyzing environmental variability at scales relevant to physiological stress. J Exp Biol 213:995-1003

Herbert RJH, Southward AJ, Sheader M, Hawkins SJ (2007) Influence of recruitment and temperature on distribution of intertidal barnacles in the English Channel. J Mar Biol Assoc UK 87:487-499
Hidas EZ, Costa T, Ayre DJ, Minchinton TE (2007) Is the species composition of rocky intertidal invertebrates across a biogeographic barrier in south-eastern Australia related to their dispersal? Mar Freshw Res 58: 835-842

Hidas EZ, Ayre DJ, Minchinton TE (2010) Patterns of demography for rocky-shore, intertidal invertebrates approaching their geographical range limits: tests of the abundant-centre hypothesis in south-eastern Australia. Mar Freshw Res 61:1243-1251

Hofmann G, Somero G (1995) Evidence for protein damage at environmental temperatures: seasonal changes in levels of ubiquitin conjugates and hsp70 in the intertidal mussel Mytilus trossulus. J Exp Biol 198:1509-1518

> Hughes L (2003) Climate change and Australia: trends, projections and impacts. Austral Ecol 28:423-443

> Huyer A, Smith RL, Stabeno PJ, Church JA, White NJ (1988) Currents off south-eastern Australia: results from the Australian coastal experiment. Aust J Mar Freshw Res 39:245-288

Jackson AC (2010) Effects of topography on the environment. J Mar Biol Assoc UK 90:169-192

> Keogh SJ, Robinson IS, Donlon CJ, Nightingale TJ (1999) The accuracy of AVHRR SST determined using shipborne radiometers. Int J Remote Sens 20:2871-2876

Knox GA (1963) The biogeography and intertidal ecology of the Australasian coasts. Oceanogr Mar Biol Annu Rev 1: 341-404

Lagos N, Navarrete SA, Veliz F, Masuero A, Castilla JC (2005) Meso-scale spatial variation in settlement and recruitment of intertidal barnacles along the coast of central Chile. Mar Ecol Prog Ser 290:165-178

Last PR, White WT, Gledhill DC, Hobday AJ, Brown R, Edgar GJ, Pecl GT (2011) Long-term shifts in abundance and distribution of a temperate fish fauna: a response to climate change and fishing practices. Glob Ecol Biogeogr 20:58-72

> Lathlean JA, Ayre DJ, Minchinton TE (2010) Supply-side biogeography: geographic patterns of settlement and early mortality for a barnacle approaching its range limit. Mar Ecol Prog Ser 412:141-150

> Lima FP, Queiroz N, Ribeiro PA, Hawkins SJ, Santos AM (2006) Recent changes in the distribution of a marine gastropod, Patella rustica Linnaeus, 1758, and their relationship to unusual climatic events. J Biogeogr 33: 812-822

Lough J (2009) Temperature. In: Poloczanska ES, Hobday AJ, Richardson AJ (eds) A marine climate change impacts and adaptation report card for Australia 2009. NCCARF Publication 05/09, Griffith

- Mace AJ, Morgan SG (2006) Larval accumulation in the lee of a small headland: implications for the design of marine reserves. Mar Ecol Prog Ser 318:19-29

Mislan KAS, Wethey DS, Helmuth B (2009) When to worry about the weather: role of tidal cycle in determining patterns of risk in intertidal ecosystems. Glob Change Biol 15:3056-3065

O'Hara TD, Poore GCB (2000) Patterns of distribution for southern Australian marine echinoderms and decapods. J Biogeogr 27:1321-1335

Poloczanska ES, Babcock RC, Butler A, Hobday A and others (2007) Climate change and Australian marine life. Oceanogr Mar Biol Annu Rev 45:407-478

Ridgway K, Hill K (2009) The East Australian Current. In: Poloczanska ES, Hobday AJ, Richardson AJ (eds) A 
marine climate change impacts and adaptation report card for Australia 2009. NCCARF Publication 05/09, Griffith

Roughan M, Middleton JH (2002) A comparison of observed upwelling mechanisms off the east coast of Australia. Cont Shelf Res 22:2551-2572

Roughan M, Middleton JH (2004) On the East Australian Current: variability, encroachment, and upwelling. J Geophys Res 109:C07003

Schiel DR, Steinbeck JR, Foster MS (2004) Ten years of induced ocean warming causes comprehensive changes in marine benthic communities. Ecology 85:1833-1839

Smale D, Wernberg T (2009) Satellite-derived SST data as

Editorial responsibility: Steven Morgan,

Bodega Bay, California, USA a proxy for water temperature in nearshore benthic ecology. Mar Ecol Prog Ser 387:27-37

Somero GN (2002) Thermal physiology and vertical zonation of intertidal animals: optima, limits, and costs of living. Integr Comp Biol 42:780-789

Underwood AJ, Denley EJ, Moran MJ (1983) Experimental analyses of the structure and dynamics of mid-shore rocky intertidal communities in New South Wales. Oecologia 56:202-219

Zacherl D, Gaines SD, Lonhart SI (2003) The limits to biogeographical distributions: insights from the northward range extension of the marine snail, Kelletia kelletii (forbes, 1852). J Biogeogr 30:913-924

Submitted: March 18, 2011; Accepted: July 23, 2011

Proofs received from author(s): October 10, 2011 